SHORT REPORT

\title{
Epidemiology of recurrent genital herpes simplex virus types 1 and 2
}

\author{
L Solomon, M J Cannon, M Reyes, J M Graber, N T Wetherall, W C Reeves, for the Task Force on \\ Herpes Simplex Virus Resistance*
}

Sex Transm Infect 2003;79:456-459

Objectives: To describe the epidemiology of type specific recurrent genital herpes, and to compare the duration of recurrent genital lesions caused by herpes simplex virus (HSV) types 1 and 2.

Methods: Participants were enrolled at clinics across the United States. Adults suspected of having active genital herpes were eligible. Lesions were cultured for HSV and typed. Data from 940 participants with recurrent culture positive HSV lesions were analysed. Pearson's $\chi^{2}$ and Fisher's exact tests, multivariate logistic regression models, and a stratified Cox proportional hazards model were used to compare epidemiological characteristics and lesion duration of HSV-1 and HSV-2.

Results: HSV-1 was present in $4.2 \%$ of the recurrent HSV culture positive lesions. HSV-1 was most prevalent among whites $(6.5 \%)$ and individuals with $0-2$ recurrences in the previous year $(9.1 \%)$ and, among men, in those with rectal/ perirectal lesions (13.2\%). Longer lesion duration was not significantly associated with virus type (hazard ratio (HR) $0.95,95 \%$ confidence interval (Cl) 0.65 to $1.38, p=0.79$ ), but was associated with male sex (HR $0.85,95 \% \mathrm{Cl} 0.74$ to $0.99, p=0.04$ ), and HIV seropositivity (HR $0.62,95 \% \mathrm{CI}$ 0.48 to $0.81, p<0.01$ ).

Conclusions: The authors found that, in the United States, recurrent genital HSV-1 is relatively rare in the STD and HIV clinic setting, especially among black people. Among men, rectal/perirectal recurrent lesions are more likely to be caused by HSV-1 than are penile lesions. In addition, lesion duration depends on sex and HIV status but not virus type. These findings shed new light on the type specific epidemiology of recurrent genital HSV, and suggest that type specific testing can inform the prognosis and management of genital herpes.

G enital herpes, a disease marked by recurrent ulcerative lesions, is one of the most prevalent sexually transmitted diseases (STDs). ${ }^{12}$ Herpes simplex virus type 2 (HSV-2) is the most common cause, but recent reports suggest that an increasing share of genital herpes is caused by herpes simplex virus type 1 (HSV-1). ${ }^{3}$

Although primary disease is similar for both genital HSV-1 and HSV $-2,{ }^{5}$ primary genital HSV-1 infection is less likely than HSV-2 infection to result in recurrent disease, ${ }^{67}$ and the

*Task Force on Herpes Simplex Virus Resistance

E R Kern, L Corey, C Crumpacker, G Darby, G Davis, P E Pellett, S Sacks, S E Straus. risk of asymptomatic viral shedding is less for patients with genital HSV-1. ${ }^{8}$ Little is known, however, about other epidemiological and clinical differences between recurrent genital HSV-I and HSV-2.

The objective of this study was to describe the epidemiology of type specific recurrent genital herpes in a large, geographically diverse sample, and to compare the duration of recurrent genital HSV-1 and HSV-2 lesions.

\section{METHODS}

Study design

Data were collected as part of a cross sectional surveillance study to assess the prevalence of aciclovir resistance in genital herpes. ${ }^{9}$ Participants were enrolled at 22 STD and HIV clinics in seven urban areas across the United States from October 1996 to April 1998. Eligible participants were 18 years and older and were suspected of having active genital herpes. Participants' genital lesions were cultured for HSV and

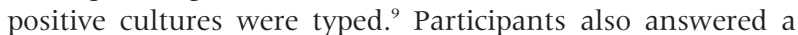
short questionnaire.

\section{Analysis}

We analysed data from 940 participants who reported a previous occurrence of genital herpes and whose current lesions cultured positive for HSV. We calculated proportions of HSV-1 and HSV-2 according to various epidemiological characteristics and evaluated significance of univariate associations using Pearson's $\chi^{2}$ and Fisher's exact tests. We used multivariate logistic regression models to identify independent risk factors for type specific infections. The final model included variables whose associated $\mathrm{p}$ value in the univariate analysis was less than 0.2 , and an interaction term for sex and lesion site.

We used a stratified Cox proportional hazards model to detect differences in the duration of genital lesions (number of days the preceding genital herpes episode lasted) caused by HSV-1 compared with those caused by HSV-2. The model stratified by race and controlled for sex, age, ethnicity, HIV status, type of sexual partners in the preceding year (none, opposite sex, same sex, both sexes), and whether the preceding episode was known to be a recurrence. Because we modelled time until the lesion healed, longer lesion duration corresponded to a smaller hazard.

\section{RESULTS}

Among the HSV positive cultures, $4.2 \%$ were positive for HSV-1 and $95.8 \%$ for HSV-2. The proportion of HSV-1 was significantly higher in white people and individuals with 0-2 recurrences in the previous 12 months and, among men, in those with rectal/perirectal lesions rather than penile lesions (table 1). Although the proportion of HSV-1 was also higher among women and individuals reporting same sex partners only, these differences were not statistically significant. In multivariate analyses, the significant associations persisted; 


\begin{tabular}{|c|c|c|c|c|c|c|c|c|}
\hline \multirow[b]{2}{*}{ Variable } & & \multicolumn{2}{|c|}{ HSV-1 } & \multicolumn{2}{|c|}{ HSV-2 } & \multirow[b]{2}{*}{ Odds ratio } & \multirow[b]{2}{*}{$95 \% \mathrm{Cl}$} & \multirow[b]{2}{*}{$\mathrm{p}$ Value } \\
\hline & & No & $\%$ & No & $\%$ & & & \\
\hline \multicolumn{9}{|l|}{ Sex } \\
\hline & Male & 20 & 3.5 & 555 & 96.5 & Referent & & \\
\hline & Female & 19 & 5.3 & 341 & 94.7 & 1.55 & (0.81 to 2.94$)$ & 0.18 \\
\hline \multicolumn{9}{|l|}{ Age } \\
\hline & $<20$ & 1 & 2.9 & 33 & 97.1 & Referent & & \\
\hline & $20-29$ & 19 & 5.1 & 352 & 94.9 & 1.78 & (0.23 to 13.73 ) & $1.0 \ddagger$ \\
\hline & $30-39$ & 9 & 2.9 & 296 & 97.1 & 1.00 & $(0.12$ to 8.17$)$ & $1.0 \ddagger$ \\
\hline & $40-49$ & 8 & 4.8 & 158 & 95.2 & 1.67 & (0.20 to 13.82$)$ & $1.0 \pm$ \\
\hline & $50-59$ & 2 & 3.8 & 50 & 96.2 & 1.32 & $(0.12$ to 15.15$)$ & $1.0 \ddagger$ \\
\hline & $60+$ & 0 & 0 & 12 & 100 & ND & ND & $1.0 \ddagger$ \\
\hline \multicolumn{9}{|l|}{ Race } \\
\hline & White & 29 & 6.5 & 418 & 93.5 & Referent & & \\
\hline & Black & 5 & 1.3 & 390 & 98.7 & 0.18 & $(0.07$ to 0.48$)$ & $<0.01$ \\
\hline & Other & 5 & 5.3 & 90 & 94.7 & 0.80 & $(0.30$ to 2.13$)$ & 0.65 \\
\hline \multicolumn{9}{|l|}{ Ethnicity } \\
\hline & Non-Hispanic & 34 & 4.2 & 785 & 95.9 & Referent & & \\
\hline & Hispanic & 4 & 4.2 & 92 & 95.8 & 1.00 & (0.35 to 2.89$)$ & $1.0 \ddagger$ \\
\hline \multicolumn{9}{|c|}{ Duration of previous lesion } \\
\hline & $0-5$ days & 14 & 3.7 & 369 & 96.3 & Referent & & \\
\hline & 6-7 days & 11 & 4.0 & 265 & 96.0 & 1.09 & (0.49 to 2.45$)$ & 0.83 \\
\hline & $8-10$ days & 5 & 4.5 & 107 & 95.5 & 1.23 & $(0.43$ to 3.50$)$ & 0.70 \\
\hline \multirow{2}{*}{\multicolumn{9}{|c|}{ Episodes in previous 12 months }} \\
\hline & & & & & & & & \\
\hline & $0-2$ & 19 & 9.1 & 191 & 90.9 & Referent & & \\
\hline & $3-4$ & 17 & 3.4 & 484 & 96.6 & 0.35 & $(0.18$ to 0.69$)$ & $<0.01$ \\
\hline & $5+$ & 3 & 1.3 & 226 & 98.7 & 0.13 & (0.04 to 0.46$)$ & $<0.01$ \\
\hline \multicolumn{9}{|c|}{$\begin{array}{l}\text { Years since } 1 \text { st genital herpes } \\
\text { lesion }\end{array}$} \\
\hline & 1 or less & 17 & 4.3 & 382 & 95.7 & Referent & & \\
\hline & $2-5$ & 15 & 5.5 & 258 & 94.5 & 1.31 & (0.64 to 2.66 ) & 0.46 \\
\hline & $6+$ & 7 & 2.6 & 261 & 97.4 & 0.60 & (0.25 to 1.47$)$ & 0.26 \\
\hline \multicolumn{9}{|c|}{ Ever used anti-herpes drugs } \\
\hline & No & 20 & 3.9 & 499 & 96.2 & Referent & & \\
\hline & Yes & 18 & 4.4 & 387 & 95.6 & 1.16 & (0.61 to 2.22 ) & 0.65 \\
\hline \multicolumn{9}{|c|}{ Aciclovir resistant isolate } \\
\hline & No & 39 & 4.2 & 886 & 95.8 & Referent & & \\
\hline & Yes & 0 & 0 & 15 & 100 & ND & ND & $1.0 \ddagger$ \\
\hline HIV status & & & & & & & & \\
\hline & Negative & 31 & 4.0 & 746 & 96.0 & Referent & & \\
\hline & Positive & 8 & 5.0 & 152 & 95.0 & 1.27 & (0.57 to 2.81$)$ & 0.56 \\
\hline $\begin{array}{l}\text { Sex partn } \\
12 \text { month }\end{array}$ & & & & & & & & \\
\hline & None & 4 & 3.9 & 99 & 96.1 & Referent & & \\
\hline & Opposite sex only & 28 & 3.8 & 716 & 96.2 & 0.97 & (0.33 to 2.82$)$ & $1.0 \ddagger$ \\
\hline & Same sex only & 7 & 9.9 & 64 & 90.1 & 2.71 & (0.76 to 9.62$)$ & $0.12 \ddagger$ \\
\hline & Both & 0 & 0 & 22 & 100 & ND & ND & $1.0 \ddagger$ \\
\hline Lesion site & & & & & & & & \\
\hline & Women only & & & & & & & \\
\hline & Vulva & 11 & 6.4 & 160 & 93.6 & Referent & & \\
\hline & Cervico-vaginal & 3 & 5.8 & 49 & 94.2 & 0.89 & (0.24 to 3.32 ) & $1.0 \ddagger$ \\
\hline & Rectal/perirectal & 3 & 7.3 & 38 & 92.7 & 1.15 & (0.31 to 4.32 ) & $0.74 \ddagger$ \\
\hline & Thigh & 1 & 1.2 & 61 & 98.4 & 0.24 & (0.03 to 1.89 ) & $0.19 \ddagger$ \\
\hline & Other & 0 & 0 & 14 & 100 & ND & ND & $1.0 \ddagger$ \\
\hline & Multiple sites & 1 & 7.1 & 13 & 92.9 & 1.12 & $(0.13$ to 9.36$)$ & $1.0 \ddagger$ \\
\hline & $\begin{array}{l}\text { Men only } \\
\text { Penis }\end{array}$ & 11 & & 434 & 97.5 & Referent & & \\
\hline & Rectal/perirectal & 9 & 13.2 & 59 & 86.8 & 6.02 & (2.39 to 3.32 ) & $<0.01 \ddagger$ \\
\hline & Thigh & 0 & 0 & 37 & 100 & ND & ND & $1.0 \ddagger$ \\
\hline & Other & 0 & 0 & 19 & 100 & ND & ND & $1.0 \ddagger$ \\
\hline & Multiple sites & 0 & 0 & 3 & 100 & ND & ND & $1.0 \ddagger$ \\
\hline
\end{tabular}

†Pearson's $\chi^{2} p$ value, except where otherwise indicated. $¥$ Fisher's exact test, two tailed $p$ value. ND, not determined because of zero cells.

in addition, among those without rectal/perirectal lesions, the proportion of HSV-1 was significantly higher in women than in men (table 2).

There was little difference between the distributions of lesion duration for HSV-1 and HSV-2 (table 1). In a stratified Cox proportional hazards model, longer lesion duration was not significantly associated with virus type (HSV-1 compared with HSV-2: HR $0.95,95 \%$ CI 0.65 to $1.38, p=0.79$ ), but was associated with male sex (HR 0.85, 95\% CI 0.74 to 0.99 , $\mathrm{p}=0.04$ ), and HIV seropositivity (HR $0.62,95 \%$ CI 0.48 to $0.81, \mathrm{p}<0.01)$.

\section{DISCUSSION}

In one of the largest studies to date of recurrent genital herpes, we examined the epidemiology of type specific HSV infection. Several aspects of the study were unique. We enrolled patients from many US geographical areas, included HIV infected patients, had sufficient patients to study recurrent genital HSV-l, and used statistical techniques that allowed for the identification of independent risk factors for type specific culture positivity and lesion duration. In this population, HSV-1 caused $4.2 \%$ of recurrent lesions. HSV-1 was more likely to be present in recurrent lesions of white 


\begin{tabular}{|c|c|c|c|c|}
\hline Variable & & Odds ratios & $95 \% \mathrm{Cl}$ & p Value \\
\hline \multicolumn{5}{|l|}{ Men } \\
\hline & No rectal lesions & Referent & & \\
\hline \multicolumn{5}{|c|}{ 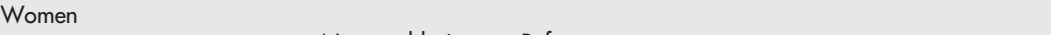 } \\
\hline & No rectal lesions & Referent & & \\
\hline & Rectal lesions & 1.08 & (0.28 to 4.09 ) & 0.92 \\
\hline \multicolumn{5}{|c|}{ Persons without rectal lesions } \\
\hline & Men & Referent & & \\
\hline & Women & 2.41 & (1.07 to 5.39$)$ & 0.03 \\
\hline \multicolumn{5}{|c|}{ People with rectal lesions } \\
\hline & Men & Referent & & \\
\hline & Women & 0.31 & (0.06 to 1.68$)$ & 0.09 \\
\hline \multicolumn{5}{|l|}{ Race } \\
\hline & White & Referent & & \\
\hline & Black & 0.16 & (0.06 to 0.42$)$ & $<0.01$ \\
\hline & Other & 0.77 & $(0.28$ to 2.14$)$ & 0.61 \\
\hline \multicolumn{5}{|c|}{$\begin{array}{l}\text { Sex partners in previous } \\
12 \text { months }\end{array}$} \\
\hline & None & Referent & & \\
\hline & Opposite sex only & 2.35 & (0.62 to 8.97$)$ & 0.21 \\
\hline & Same sex only & 2.02 & (0.51 to 8.00$)$ & 0.31 \\
\hline & Both & ND & & \\
\hline \multicolumn{5}{|c|}{$\begin{array}{l}\text { Number of episodes in previous } \\
12 \text { months }\end{array}$} \\
\hline & $0-2$ & Referent & & \\
\hline & $3-4$ & 0.33 & $(0.16$ to 0.67$)$ & $<0.01$ \\
\hline & $5+$ & 0.09 & (0.03 to 0.33 ) & 0.02 \\
\hline
\end{tabular}

people, individuals with few recurrences during the past year and, among men, in rectal/perirectal lesions rather than penile lesions. Lesion duration did not vary by HSV type, but did vary by sex and HIV status.

The percentage of recurrent lesions caused by HSV-1 $(4.2 \%)$ was considerably less than the percentage of first episode lesions caused by HSV-1 (14.6\%) in other participants at the same clinical sites (Jevitt et al, in preparation); this is consistent with reports that genital HSV-1 recurs less frequently than genital HSV-2. ${ }^{6}{ }^{10}$ This conclusion is also supported by the higher prevalence of HSV-1 among individuals with fewer recurrences during the past year (table 2). The proportion of recurrent lesions caused by HSV-1 $(4.2 \%)$ was less than half that reported by Lafferty et al $(9.9 \%) .{ }^{10}$ This difference does not appear to be explained by differences in sex practices, as our HSV-1 percentages were less within the subgroups of heterosexual men, heterosexual women, and men who have sex with men (MSM). The differences might be due to overall differences in the patient populations, because our study was from numerous clinical sites of wide geographical distribution within the United States whereas Lafferty et al ${ }^{10}$ enrolled patients at one STD clinic in Seattle.

The ratio of HSV-1 prevalence in black compared to white people was similar for recurrent $(1.3 \% \vee 6.5 \%$, odds ratio $(\mathrm{OR})=0.18)$ and first episode lesions $(5 \% \vee 27 \%, \mathrm{OR}=0.1)$ (Jevitt et al, in preparation), suggesting that genital HSV-1 recurrence rates do not differ by race, but that white people are simply more likely to be genitally infected with HSV-1. This difference may be due to white people having a higher frequency of receptive oral $\operatorname{sex}^{11}$ or being less likely to have acquired oral HSV-1 at an early age. ${ }^{12}$

Recurrent rectal/perirectal lesions in men were significantly more likely to be caused by HSV-1 than were recurrent penile lesions $(\mathrm{OR}=8.4$ ). This was also true for first episode lesions but differences by anatomical site were less marked $(\mathrm{OR}=2.6) \quad$ (Jevitt et al, in preparation), suggesting that
HSV-1 is both more likely to infect the rectal/perirectal region and more likely to recur in individuals whose primary lesions were in this region. Among MSM, the higher prevalence of HSV-1 in rectal/perirectal lesions might be explained by oral/ anal transmission of HSV-1, either by oral-anal contact or by use of saliva as a lubricant for anal sex.

Finally, recurrent lesion duration did not differ by viral type: a finding recently reported by Engelberg et al. ${ }^{7}$ Our study adds the observation that the lack of difference is not due to confounding by variables such as sex, race, sexual orientation, or lesion site. Our results are consistent with the previously established association between longer lesion duration in men ${ }^{13}$ and HIV infected individuals. ${ }^{2}$

In summary, we found that in the United States, recurrent genital HSV-1 is relatively rare in the general STD and HIV clinic setting, especially among black people. Among men, rectal/perirectal recurrent lesions are more likely to be caused by HSV-1 than are penile lesions. In addition, lesion duration depends on sex and HIV status but not virus type. These findings shed new light on the type specific epidemiology of recurrent genital HSV, and suggest that type specific testing can inform the prognosis and management of genital herpes.

\section{DISCLAIMER}

The use of trade names and commercial sources is for identification only and does not imply endorsement by the Centers for Disease Control and Prevention or the US Department of Health and Human Services.

\section{ACKNOWLEDGEMENTS}

Study site principal investigators and coordinators: Aberg J, Anthony R, Barth B, Beckholt A, Bennett M, Bradley M, Brown S, Butler O, Cathcart R, Celum C, Charles S, Clark L, Clark R, DiCarlo R, Dickes J, Dorian K, Douglas J, Enriquez R, Fife K, Flood J, Forester G, Gnann J, Gunkle S, Hansfield H, Heeren D, Henly M, Hodges C, Hogan S, Islam N, Jadeck R, Johnson I, Kaye S, Kee R, Kendrick S, Lampiris H, Lennox J, Lopez D, Marion S, Martin D, Moriera L, Mravca-Wilkey V, Murphy V, Novack R, Ocbamichael N, Ogard N, Page J, Powel J, 
Purcell ML, Remington ML, Ritiano M, Rowniak S, Savant-Herndon R, Severson M, Smith S, Somera D, Stern J, Telzak E, Thimpson G, Todd-Turner M, Tyring S, Wald A, Walthuaer D, Wasterholm J, Yu V. Glaxo Wellcome: Davis M, Hill J, Schultz M, Delahanty J, Biron K. Smith-Kline Beecham: Copeland J, Boon R. ViroMed Laboratories: Hodges-Savola C, Zimmerman T. Centers for Disease Control and Prevention: House J, Schmid DS. University of Alabama at Birmingham: Harden E.

\section{CONTRIBUTORS}

LS was responsible for the analysis and interpretation of the data and drafting of the manuscript; MC supervised the analysis and interpretation and provided critical revision of the manuscript for important intellectual content; MR was the principal investigator for this study and assisted in revision of the manuscript; JG was an investigator for this study and assisted in revision of the manuscript; NW directed the laboratory component of this study and assisted in revision of the manuscript; WR supervised this investigation and assisted in revision of the manuscript.

\section{Authors' affiliations}

L Solomon, M J Cannon, M Reyes, J M Graber, W C Reeves, Division of Viral and Rickettsial Diseases, National Center for Infectious Diseases, Centers for Disease Control and Prevention, Atlanta, GA, USA

N T Wetherall, ViroMed Laboratories, Inc, Minneapolis, MI, USA

Current affiliations and addresses for authors who have moved since completion of the study: M Reyes, Division of Nutrition and Physical Activity, National Center for Chronic Disease Prevention and Health Promotion, Centers for Disease Control and Prevention, Mail Stop K-26, Koger Office Park, Chamblee, GA 30341, USA; J M Graber: Maine Bureau of Health, Key Plaza, 11 State House Station, Augusta, ME 04333, USA; N T Wetherall: Cambridge Biomedical Research Group, 1256 Soldiers Field Road, Brighton, MA 02135, USA; L Solomon, Department of Epidemiology and Surveillance Research, American Cancer Society, 1599 Clifton Road, Atlanta, GA 30329, USA.
Correspondence to: William C Reeves, MD, Centers for Disease Control and Prevention, Mail Stop A-15, 1600 Clifton Road, Atlanta,

GA 30333, USA; wcr1@cdc.gov

Accepted for publication 19 June 2003

\section{REFERENCES}

1 Stanberry L, Cunningham A, Mertz G, et al. New developments in the epidemiology, natural history and management of genital herpes. Antiviral Res 1999;42:1-14

2 Sexually transmitted diseases treatment guidelines 2002. Centers for Disease Control and Prevention. MMWR 2002;51(No. RR-6): 1-78.

3 Ribes JA, Steele AD, Seabolt JP, et al. Six-year study of the incidence of herpes in genital and nongenital cultures in a central Kentucky medical center patient population. J Clin Microbiol 2001;39:3321-25

4 Scoular A, Norrie J, Gillespie G, et al. Longitudinal study of genital infection by herpes simplex virus type 1 in western Scotland over 15 years. BMJ 2002;324:1366-7.

5 Corey L, Adams HG, Brown ZA, et al. Genital herpes simplex virus infections: clinical manifestations, course, and complications. Ann Intern Med 1983;98:958-72

6 Benedetti J, Corey L, Ashley R. Recurrence rates in genital herpes after symptomatic first-episode infection. Ann Intern Med 1994; 121:847-54.

7 Engelberg R, Carrell D, Krantz E, et al. Natural history of genital herpes simplex virus type 1 infection. Sex Transm Dis 2003;30:174-7.

8 Wald A, Zeh J, Selke S, et al. Virologic characteristics of subclinical and symptomatic genital herpes infections. N Engl J Med 1995:333:770-5.

9 Reyes M, Shaik NS, Graber JM, et al. Acyclovir-resistant genital herpes among persons attending sexually transmitted disease and human immunodeficiency virus clinics. Arch Intern Med 2003;163:76-80.

10 Lafferty WE, Downey L, Celum C, et al. Herpes simplex virus type 1 as a cause of genital herpes: impact on surveillance and prevention. $J$ Infect Dis 2000;181:1454-7.

11 Michael RT, Laumann EO, Kolata G. Practices and preferences. In: Sex in America. 1st ed. Boston: Little, Brown, 1994:132-54.

12 Siegel $D$, Golden $E$, Washington $A E$, et al. Prevalence and correlates of herpes simplex infections: the population-based AIDS in multiethnic neighborhoods study. JAMA 1992;268:1702-8.

13 Mindel A, Coker DM, Faherty A, et al. Recurrent genital herpes: clinical and virological features in men and women. Genitourin Med 1988;64:103-6.

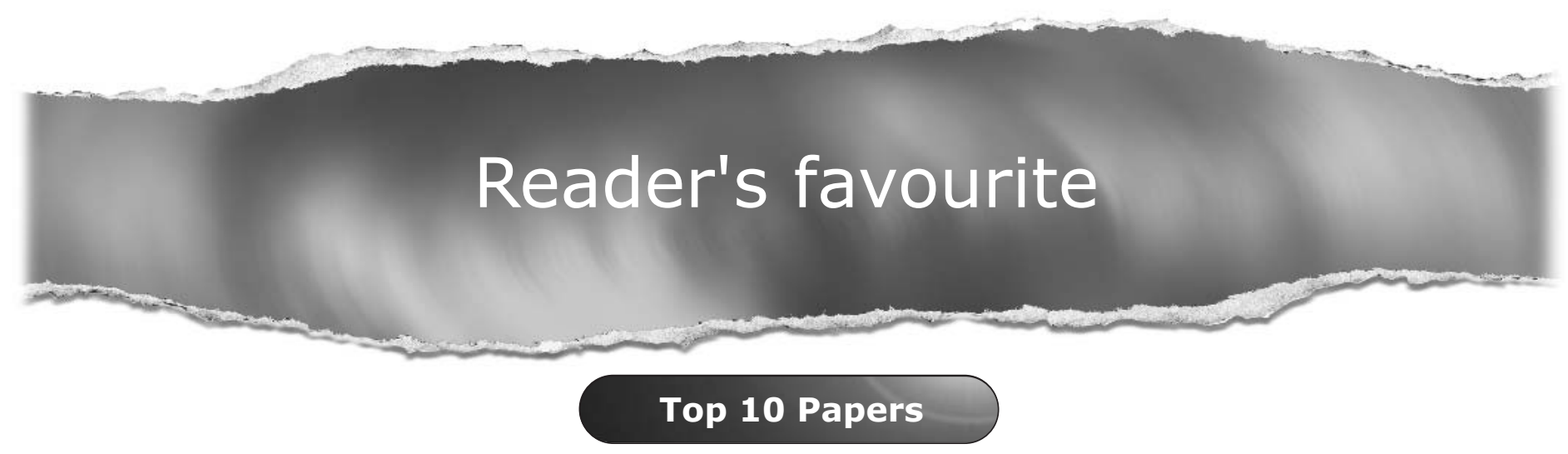

Click on the "Top 10 Papers" button on the homepage to see which are the best read articles updated monthly.

www.stijournal.com 